Med Hypotheses. 2013 April ; 80(4): 411-415. doi:10.1016/j.mehy.2012.12.030.

\title{
Stroke in the Eye of the Beholder
}

\author{
Hiroto Ishikawa ${ }^{1,{ }^{*}}$, Mathew Caputo ${ }^{1,{ }^{*}}$, Nicholas Franzese ${ }^{1,{ }^{*},}$, Nathan L. Weinbren ${ }^{1,{ }^{*}}$, Adam \\ Slakter $^{1}$, Milan Patel ${ }^{1}$, Christine E. Stahl ${ }^{2}$, Maria Alejandra Jacotte ${ }^{3}$, Sandra Acosta ${ }^{1}$, \\ Giorgio Franyuti ${ }^{4}$, Kazutaka Shinozuka ${ }^{1}$, Naoki Tajiri ${ }^{1}$, Harry van Loveren ${ }^{1}$, Yuji Kaneko ${ }^{1}$, \\ and Cesar V. Borlongan ${ }^{1}$ \\ ${ }^{1}$ Department of Neurosurgery and Brain Repair, 12901 Bruce B. Downs Blvd. University of South \\ Florida, Tampa, FL 33612, USA \\ ${ }^{2}$ Department of Aerospace Medicine, MacDill Air Force Base, Tampa, Florida 33611 USA \\ ${ }^{3}$ Dept. Psicobiología y Metodología, Instituto de Neurociencias, Facultad de Psicología Edificio B, \\ Universidad Autónoma de Barcelona, 08193 Bellaterra, Barcelona-España \\ ${ }^{4}$ Neuroimmunology Department, Medical School, Anahuac University, Camina Research Center \\ Tlalpan No. 4430 Mexico City, Mexico
}

\begin{abstract}
The pathophysiological changes that occur during ischemic stroke can have a profound effect on the surrounding nerve tissue. To this end, we advance the hypothesis that retinal damage can occur as a consequence of ischemic stroke in animal models. We discuss the preclinical evidence over the last 3 decades supporting this hypothesis of retinal damage following ischemic stroke. In our evaluation of the hypothesis, we highlight the animal models providing evidence of pathological and mechanistic link between ischemic stroke and retinal damage. That retinal damage is closely associated with ischemic stroke, yet remains neglected in stroke treatment regimen, provides the impetus for recognizing the treatment of retinal damage as a critical component of stroke therapy.
\end{abstract}

\section{Introduction: An Eye Opener to Cerebral Ischemia}

Ischemia generally refers to a restriction in blood supply. An ischemic stroke occurs when blood supply is disrupted to a location in the brain, preventing oxygen and nutrients from being delivered and resulting in the development of an infarcted area. Retinal ischemia is a condition that occurs when blood, carrying oxygen and nutrients, is cut off from the retina, preventing it from fulfilling its metabolic demands. Because the retina is an extension of the central nervous system (CNS), physiological response to retinal ischemia is very similar to ischemic stroke [1]. Retinal ischemia is a known cause of blindness as well as being associated with stroke [1]. However, little attention has been given to the pathological association between retinal ischemia and stroke. Here, we advance the hypothesis, based on preclinical evidence, that ischemic stroke causes retinal damage. Furthermore, we make the

\footnotetext{
(C) 2013 Elsevier Ltd. All rights reserved.

Correspondence should be addressed to: Cesar V. Borlongan, Professor and Vice-Chairman for Research, Department of Neurosurgery, 12901 Bruce B. Downs Blvd. University of South Florida, Tampa, FL 33612, USA, Tel: +1 813974 3154; Fax: +1 813 974 3078; cborlong@health.usf.edu.

Authors who equally contributed to this paper.

Publisher's Disclaimer: This is a PDF file of an unedited manuscript that has been accepted for publication. As a service to our customers we are providing this early version of the manuscript. The manuscript will undergo copyediting, typesetting, and review of the resulting proof before it is published in its final citable form. Please note that during the production process errors may be discovered which could affect the content, and all legal disclaimers that apply to the journal pertain.
} 
argument that treatment of retinal damage should be included as a regular therapy to treat ischemic stroke. We also provide examples of possible treatments for retinal ischemia.

\section{Eyeballing the Pathological Link Between Ischemic Stroke and Retinal Injury}

Ischemic stroke has been shown to cause massive retinal damage, yet little attention has been given to treating eye-related abnormalities in stroke patients (Figure 1). In fact, retinal damage has been observed in several animal models of cerebral ischemia. After 30 minutes of simulated ischemia in vitro, rabbit retinas show an inability to fully recover from the damage sustained, showing a decrease in protein synthesis of over 50\% [2]. This damage is not limited to in vitro models, but also occurs in vivo. About $58 \%$ of a group of rats given permanent bilateral occlusion of common carotid arteries showed a reduction in retinal ganglion cell layer neurons [3]. The damage to this group also extended into macro level functions, resulting in loss of pupillary reflex in the same 58\% of animals [3]. A second study confirms these results, showing loss of pupillary reflex in 14 out of 25 rats given permanent bilateral occlusions of the common carotid arteries, the same 14 showing degeneration of the retina [4]. After 60 minutes of filamentous middle cerebral artery occlusion (MCAo) and a subsequent 2 hours post reperfusion, extensive retinal cell damage was observed in a mouse model [5]. Cell damage in the inner nuclear and ganglion layers was observed after 60 minutes of MCAo. However, two days after 30 minutes of MCAo did not produce significant retinal damage in mice. The varying outcomes of these trials cannot be attributed to the differences in subject animals, as all mice were seven weeks old, of the same strain, and male. Rather, the differences are likely due to the different lengths of time for which the MCA was occluded in each of the models. Retinal damage was only observed after the significantly longer MCAo of 60 minutes, suggesting that a relatively severe and long ischemic injury is required to induce retinal damage [5].

Interestingly, not all MCAo resulted in significant retinal damage. Rats subjected to both transient and permanent MCAo for a period of 60 minutes did not exhibit any significant morphological changes in the retina [6]. Despite the absence of overt morphological alterations, expression of hypoxia-inducible factor 1 alpha (HIF-1alpha) and of heat shock protein (HSP) genes did reveal that the retinal neurons were experiencing ischemic stress [6]. These different results could be attributed to the fact that this experiment used rats while the other used mice or even to the fact that different methods were used to induce MCAo. Rats and mice have been shown to possess different metabolic activity in response to stress. For example, when challenged with Tetrachlorodibenzo-p-dioxin, a herbicide that has shown to have harmful effects on organisms, mice exhibited an upregulated CD36, a protein associated with fatty acid and glucose metabolism, whereas rats demonstrated a decrease in CD36 expression [7], which could have influenced the resulting retinal damage or lack thereof, following ischemic stroke in rats and mice. Alternatively, the relationship between retinal damage and ischemic injury may be a complex pathophysiological cascade of events. In this case, although there is a constant 60 minute MCAo, the possible differences in energy metabolism between rats and mice could have resulted in varying retinal injury even though there was a consistent ischemic stroke. Accordingly, ischemic stroke lasting for long periods of time is an extremely devastating injury that could result in a multitude of damaging results, retinal injury being one of these deleterious consequences. 


\section{A Bird's Eye View of the Mechanistic Cell Death Accompanying Ischemic Stroke and Retinal Damage}

Occlusion of a blood vessel more closely related to the retina could consistently produce retinal damage. Ischemic stroke brought on by branch retinal vein occlusion (BRVo) in mini-pigs has been shown to induce massive retinal damage. Within 4-24 hours after BRVo, necrosis was observed in the affected areas of the retinas. Following necrosis, a cascade of apoptotic cell death ensued. This wave of cell death was localized mainly in the periphery of the affected retinal cells. Around 1-3 weeks after BRVo, atrophy of the inner retina was observed [8]. These results reinforce the notion that retinal damage is a consequential pathological event of ischemic stroke.

Recent evidence suggests that certain conditions can exacerbate retinal damage caused by ischemic stroke. One study indicates that type 2 diabetes, characterized by high blood glucose levels, can intensify retinal damage brought on by ischemic injury. The study took two groups of all male mice, one group with diabetes and the other without, and induced retinal ischemia using transient MCAo. The results showed significantly more ischemic damage in the retinas of the diabetic mice than in the non-diabetic ones [9]. The high levels of blood glucose levels that characterize type 2 diabetes translates to lower levels of cell glucose levels. Low levels of glucose in cells combined with hypoxia brought on by ischemic stroke could prove devastating. Not only will hypoxia prevent the cells from carrying out the aerobic stages of respiration, but also a lack of glucose will prevent the cell even from carrying out the anaerobic process of glycolysis sooner than in mice without diabetes. These results indicate that it might be beneficial to check for diabetic conditions in patients when treating ischemic stroke.

Moreover, hypertension or high blood pressure has been shown to exacerbate neuronal damage due to ischemic injury. Ischemic injury was induced by applying endothelin-1, a vasoconstrictor, in the vicinity of the middle cerebral artery in both control rats and rats with spontaneous hypertension. Using the neurological deficit score, the sensory and motor functions of each group was measured. The group of rats with hypertension exhibited significantly more sensory and motor deficits than the control rats. Although these changes disappeared between 24 and 72 hours, significantly reduced microglial activation was observed in the hypertension rat group [10]. The observed results suggest that, like ischemic stroke victims with diabetic conditions, it may be beneficial to take into account hypertension when treating ischemic injury.

\section{A Visionary Approach at Treating Ischemic Stroke-Induced Retinal Damage}

Based on the accumulating evidence that ischemic stroke can cause retinal damage, there is an urgent need to find therapies to treat retinal damage caused by ischemic stroke. Many studies have revealed promising therapeutic approaches. In diabetic mice exposed to ischemic stroke [9], a possible treatment to reduce diabetes' exacerbation of ischemic retinal damage was tested. Aldose reductase (AR) is the first enzyme in the enzymatic polyol pathway associated with diabetes. Transient MCAo was performed in both diabetic mice and diabetic mice with an AR null mutation. Reduced retinal swelling and neurological deficit was observed in the mice with the null mutation [9]. These results suggest that inhibition of AR could be used to reduce exacerbation of retinal ischemic injury in diabetic individuals.

Targeting upstream and downstream pathways of cellular death may ameliorate retinal damage. Suppression of semaphorin 3A, a chemical secreted by hypoxic neurons, could prevent the vascular decay that accompanies ischemic injury to the retina in mice [11]. Gerbils subjected to ischemia-reperfusion injury and given Daflon $500 \mathrm{mg}$, a flavonoid drug, 
displayed a reduction in hydroxyl free radicals, which can be particularly damaging to retinal tissues [12]. In parallel, gerbils treated with piribedil, a D-2 agonist, and exposed to ischemia-reperfusion injury exhibited a reversal of the increase of excitatory amino acids and hydroxyl free radicals, affording a neuroprotective effect that could prevent damage to the retina [13]. Mice pretreated with extracts of the Chinese fruit Lycium barbarum and then subjected to two hour transient middle cerebral artery occlusion exhibited neuroprotective effects in the retina [14]. Thalidomide, a controversial drug linked to birth defects that has been used as a sedative and, more recently, to treat multiple myeloma [15], could be a viable candidate to inhibit neuronal damage in the retina after ischemia. Recently, thalidomide has been shown to exert neuroprotective effects against ischemic neural damage in that mice subjected to MCAo and treated with the drug exhibited a significant reduction in the size of the infarct area, as well as an improvement in neurological functionality post ischemic injury [15]. By preventing the necrosis of neurons in the mouse brains, thalidomide could later be used to preserve the integrity of some of the neural circuits responsible for vision [15]. Another therapeutic approach revealed that NR3A, a subunit of NMDA-type glutamate receptors (NMDARs) present in certain neurons, exhibits neuroprotective effects that could be utilized therapeutically to prevent neuronal and retinal damage [16]. Because the hyperactivation of NMDARs causes excitotoxicity, which contributes to neuronal damage [16], exogenously administered NR3A could decrease stimulation by the neurotransmitter glutamate and thus prevent nerve cell death and damage [16]. In an effort to combat the inflammation implicated as a major secondary cell death mechanism after ischemic stroke and retinal damage, the inhibition of NF-kappa B, a protein complex involved in regulation of the inflammatory response, has been shown to exert neuroprotective effects in retinal neurons [17]. When retinal ischemia was induced in a mouse model, mice with an inactivated NF-kappa B gene showed a substantial increase in the survivability of neurons located in the ganglion cell layer post ischemic injury compared to wild-type mice [17]. Thus, identifying a neuroprotectant that acts directly on retinal neurons may prove beneficial against retinal damage. Transgenic mice with deletion of the toll-like receptor (TLR)-4, a component of innate immune system that is activated by an infectious agent, displayed resilient against ischemic damage. The deficiency helped to reduce parenchymal stress in the retinal ganglion cells (RGCs) [18] TLR-4 deprivation may prove an effective neuroprotective strategy in dealing with ischemic injury in the retina. Investigations into the cells most directly affected by optic nerve stroke may open new avenues for treating retinal ischemia. Of note, brain-expressed X-linked (Bex) proteins are highly expressed in RGCs, the cells most directly affected by optic nerve stroke. Post-stroke, accumulation of Bex immunoreactivity in the RGC cytoplasm was observed suggesting that the long-and shortterm effects of optic nerve stroke on the retina can be evaluated by observing Bex immunoreactivity [19]. Bex immunoreactivity can, therefore, be utilized in therapies to identify the extent of retinal damage caused by ischemic stroke.

Nonarteritic anterior ischemic optic neuropathy (NAION) is a type of white-matter central nervous system (CNS) stroke resulting from isolated ischemia near the retina-optic nerve $(\mathrm{ON})$ junction. NAION, a known cause of blindness, is similar to other strokes affecting the CNS, so treatments for NAION might be effective for treating retinal damage from other types of ischemic stroke. Induction of NAION in a rodent model led to inflammatory response characterized by reduced macrophage ED1(+) cells, but a surge in numbers of microglial Iba1(+)cells in in the anterior ON region [20]. NAOIN is similar to other ischemic strokes in the fact that it causes the early recruitment of macrophages to the infarct region. Thus, manipulating the inflammatory and neuroregenarative process of NAION may assist in the treatment of retinal damage from other forms of ischemic stroke. In summation, experimental therapies directed at multiple levels of cell death pathways show potential to promote retinal health in victims of ischemic stroke. Similarly, these therapies effective at attenuating retinal damage may prove beneficial to other cerebrovascular diseases. In the 
same token, therapies shown to be effective in stroke-related disorders may afford beneficial effects on retinal damage. For example, erythropoietin's robust protective effects against neurodegeneration of retinal ganglion cells [21] or axotomy of the retinal ganglion cells [22] may likely exert similar benefits in ischemic stroke-induced retinal damage. Other therapeutic practices including Tacrolimus, an immunosuppressant shown to suppress leukocyte accumulation in the retina after temporary ligation of the optic sheath [23] and GM1, a ganglioside [24], may also abrogate the ischemic stroke-induced retinal damage.

A variety of animal models could be viable platforms for approximation of retinal ischemia in humans. A mouse model of transient retinal ischemia exhibited upregulation of early genes and persistent functional deficits that are characteristic of retinal ischemia [25]. In addition, NAION was induced in a primate model through a photoembolic technique, resulting in many pathophysiologic symptoms reminiscent of retinal ischemia in humans [26]. Table 1 reviews the data generated in animal models of stroke resulting in retinal damage.

\section{Conclusion}

The pathology of retinal ischemia after stroke, its mechanism of cell death, and finally the potential therapeutic regiments to arrest this understudied disease may benefit from highly reproducible, validated and standardized animal models that closely mimic the clinical disease manifestations. Laboratory investigations testing this hypothesis of stroke-induced retinal damage will form the basis for differential diagnosis of retinal damage consequent of stroke, thereafter providing the rationale for treatment of retinal damage as a core regimen in stroke therapy.

\section{Acknowledgments}

Sources of support: CVB is supported by James and Esther King Foundation for Biomedical Research Program and NIH NINDS RO1 1R01NS071956-01.

\section{References}

1. Minhas G, Morishita R, Anand A. Preclinical models to investigate retinal ischemia: advances and drawbacks. Front Neurol. 2012; 3:75. [PubMed: 22593752]

2. Ames A, Nesbett FB. Pathophysiology of ischemic cell death: I. Time of onset of irreversible damage; importance of the different components of the ischemic insult. Stroke. 1983; 14(2):219226. [PubMed: 6836647]

3. Stevens WD, Fortin T, Pappas BA. Retinal and optic nerve degeneration after chronic carotid ligation: time course and role of light exposure. Stroke. 2002; 33(4):1107-1112. [PubMed: 11935068]

4. Davidson CM, Pappas BA, Stevens WD, Fortin T, Bennett SA. Chronic cerebral hypoperfusion: loss of pupillary reflex, visual impairment and retinal neurodegeneration. Brain Res. 2000; 859(1): 96-103. [PubMed: 10720618]

5. Steele EC Jr, Guo Q, Namura S. Filamentous middle cerebral artery occlusion causes ischemic damage to the retina in mice. Stroke. 2008; 39(7):2099-2104. [PubMed: 18436885]

6. Kalesnykas G, Tuulos T, Uusitalo H, Jolkkonen J. Neurodegeneration and cellular stress in the retina and optic nerve in rat cerebral ischemia and hypoperfusion models. Neuroscience. 2008; 155(3):937-947. [PubMed: 18640247]

7. Forgacs AL, Kent MN, Makley MK, et al. Comparative metabolomics and genomic analyses of TCDD-elicited metabolic disruption in mouse and rat liver. Toxicol Sci. 2012; 125(1):41-55. [PubMed: 21964420] 
8. Donati G, Kapetanios A, Dubois-Dauphin M, Pournaras CJ. Caspase-related apoptosis in chronic ischaemic microangiopathy following experimental brain occlusion in mini-pigs. Acta Opthalmol. 2008; 86(3):302-306.

9. Yeung CM, Lo AC, Cheung AK, et al. More severe type 2 diabetes-associated ischemic stroke injury is alleviated in aldose reductase-deficient mice. J Neurosci Res. 2010; 88(9):2026-2034. [PubMed: 20143423]

10. De Geyter D, Stoop W, Zgavc T, et al. Spontaneously hypertensive rats display reduced microglial activation in response to ischemic stroke and lipopolysaccharide. J Neuroinflammation. 2012; 9(1):114. [PubMed: 22647642]

11. Joyal JS, Sitaras N, Binet F, et al. Ischemic neurons prevent vascular regeneration of neural tissue by secreting semoraphin 3A. Blood. 2011; 117(22):6024-6035. [PubMed: 21355092]

12. Delbarre B, Delbarre G, Calinon F. Effect of Daflon $500 \mathrm{mg}$, a flavonoid drug, on neurological signs, levels of free radicals and electroretinogram in the gerbil after ischemia-reperfusion injury. Int J Microcirc Clin Exp. 1995; 15:27-33. [PubMed: 8748886]

13. Delbarre B, Delbarre G, Rochat C, Calinon F. Effect of piribedil, a D-2 dopaminergic agonist, on dopamine, amino acids, and free radicals in gerbil brain after cerebral ischemia. Mol Chem Neuropathol. 1995; 26(1):42-52.

14. Yang D, Li SY, Yeung CM, et al. Lycium barbarum extracts protect the brain from blood-brain barrier disruption and cerebral edema in experimental stroke. PLoS One. 2012; 7(3):e33596. [PubMed: 22438957]

15. Hyakkoku K, Nakajima Y, Izuta H, et al. Thalidomide protects against ischemic neuronal damage induced by focal cerebral ischemia in mice. Neuroscience. 2009; 159(2):760-769. [PubMed: 19166916]

16. Nakanishi N, Tu S, Shin Y, et al. Neuroprotection by the NR3A subunit of the NMDA receptor. J Neurosci. 2009; 29(16):5260-5265. [PubMed: 19386922]

17. Dvoriantchikova G, Barakat D, Brambilla R, et al. Inactivation of astroglial NF-kappa B promotes survival of retinal neuron following ischemic injury. Eur J Neurosci. 2009; 30(2):175-185. [PubMed: 19614983]

18. Kilic U, Kilic E, Matter CM, Bassetti CL, Hermann DM. TLR-4 deficiency protects against focal cerebral ischemia and axotomy-induced neurodegeneration. Neurobiol Dis. 2008; 31(1):33-40. [PubMed: 18486483]

19. Bernstein SL, Koo JH, Slater BJ, Guo Y, Margolis FL. Analysis of optic nerve stroke by retinal Bex expression. Mol Vis. 2006; 12:147-155. [PubMed: 16541015]

20. Zhang C, Guo Y, Miller NR, Bernstein SL. Optic nerve infarction and post-ischemic inflammation in the rodent model of anterior ischemic optic neuropathy (rAION). Brain Res. 2009; 1264:67-75. [PubMed: 19401181]

21. Kilic UE, Kilic J, Soliz Bassetti CL, Gassmann M, Hermann DM. Erythropoietin protects from axotomy-induced degeneration of retinal ganglion cells by activating ERK-1/-2. FASEB J. 2005; 19(2):249-251. [PubMed: 15556972]

22. Weishaupt JH, Rohde G, Polking E, Siren AL, Ehrenreich H, Bähr M. Effect of erythropoietin axotomy-induced apoptosis in rat retinal ganglion cells. Invest Ophthalmol Vis Sci. 2004; 45(5): 1514-1522. [PubMed: 15111610]

23. Tsujikawa A, Ogura Y, Hiroshiba N, Miyamoto K, Kiryu J, Honda Y. Tacrolimus (FK506) attenuates leukocyte accumulation after transient retinal ischemia. Stroke. 1998; 29(7):1431-1438. [PubMed: 9660400]

24. Mohand-Said S, Weber MD, Hicks D, Dreyfus H, Sahel JA. Intravitreal injection of ganglioside GM1 after ischemia reduces retinal damage in rats. Stroke. 1997; 28(3):617-621. [PubMed: 9056621]

25. Lelong DC, Bieche I, Perez E, et al. Novel mouse model of monocular amaurosis fugax. Stroke. 2007; 38(12):3237-3244. [PubMed: 17975099]

26. Chen CS, Johnson MA, Flower RA, Slater BJ, Miller NR, Bernstein SL. A primate model of nonarteritic anterior ischemic optic neuropathy. Invest Ophthalmol Vis Sci. 2008; 49:2985-2992. [PubMed: 18326695] 


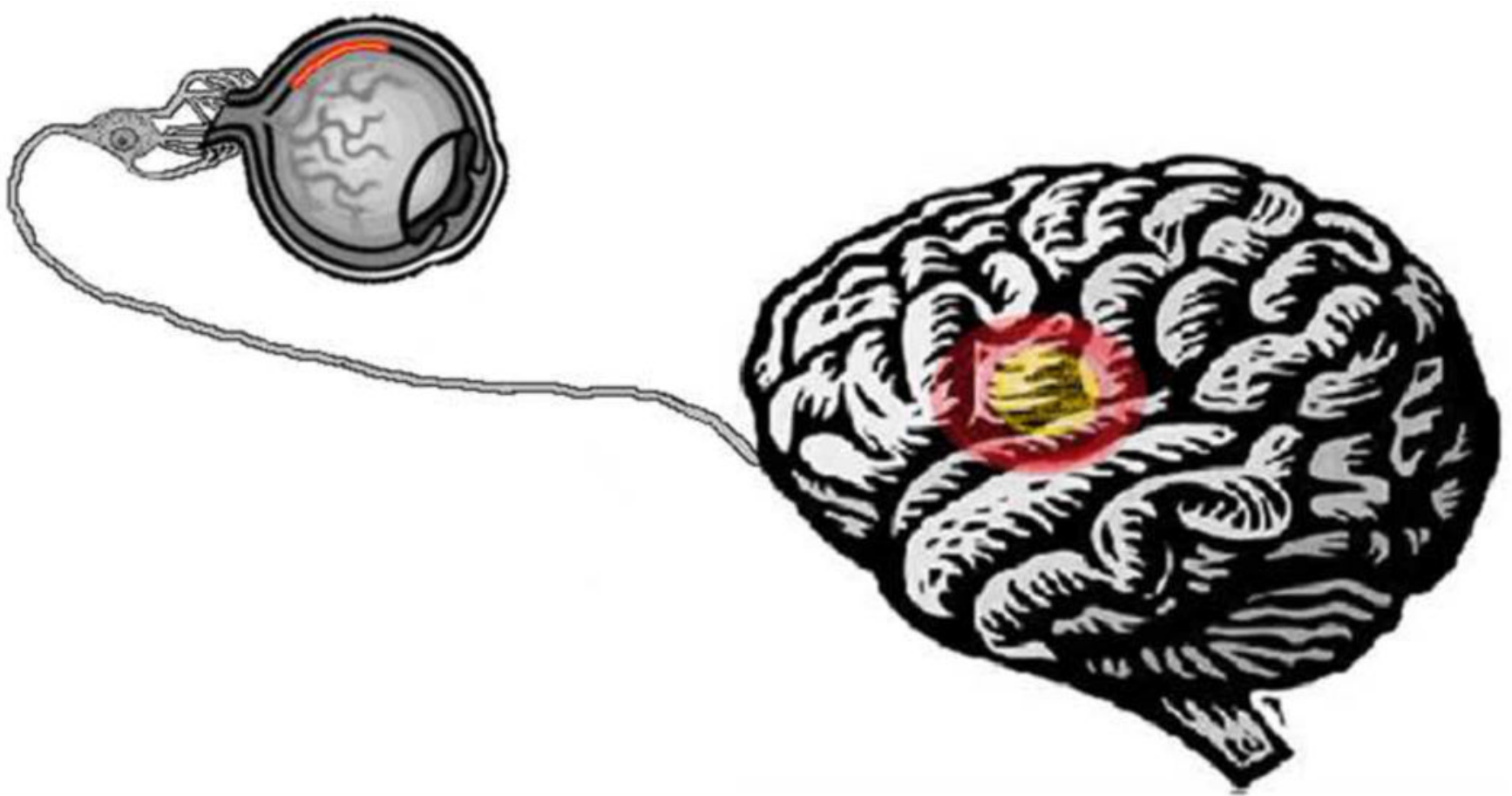

Figure 1. Eyeballing the Stroke

Ischemic stroke has been hypothesized to be as a possible cause for retinal ischemia. Stroke therapy should pay close attention to retinal damage since the lack of treatment could lead to further retinal damage and blindness. 
Table 1

\begin{tabular}{|c|c|c|c|c|}
\hline Date & Article & Author & Category & Description \\
\hline 1983 & $\begin{array}{l}\text { Pathophysiology of ischemic cell } \\
\text { death: I. Time of onset of } \\
\text { irreversible damage; importance } \\
\text { of the different components of } \\
\text { the ischemic insult. }\end{array}$ & $\begin{array}{l}\text { Ames A, } \\
\text { Nesbett FB }\end{array}$ & Pathological & $\begin{array}{l}\text { Studies the effect of various lengths of ischemia on rabbit } \\
\text { retinas in vitro in order to pinpoint the onset of cell death. } \\
\text { Results showed that after } 20 \text { minutes of ischemia, the retina } \\
\text { cells could recover but after } 30 \text { minutes there was extensive } \\
\text { irreversible damage. }\end{array}$ \\
\hline 1983 & $\begin{array}{l}\text { Pathophysiology of ischemic cell } \\
\text { death: II. Changes in plasma } \\
\text { membrane permeability and cell } \\
\text { volume. }\end{array}$ & $\begin{array}{l}\text { Ames A 3rd, } \\
\text { Nesbett FB }\end{array}$ & Pathological & $\begin{array}{l}\text { Studies the effect of changes in cell volume on cell death } \\
\text { related to ischemic insult using rabbit retinas in vitro. Results } \\
\text { show that cell swelling correlated closely with loss of viability } \\
\text { as evidenced by failure to reinstitute protein synthesis, but the } \\
\text { swelling appeared to be the consequence rather than the cause } \\
\text { of the initial irreversible damage. }\end{array}$ \\
\hline 1983 & $\begin{array}{l}\text { Pathophysiology of ischemic cell } \\
\text { death: III. Role of extracellular } \\
\underline{\text { factors. }}\end{array}$ & $\begin{array}{l}\text { Ames A 3rd, } \\
\text { Nesbett FB }\end{array}$ & Pathological & $\begin{array}{l}\text { Studies the effect of extracellular changes that occur during } \\
\text { ischemia on cell survival through deprivation of } \mathrm{O} 2 \text { and } \\
\text { substrate of rabbit retina cells in vitro. Results demonstrate that } \\
\text { recovery is significantly effected by changes in the } \\
\text { extracellular fluid resulting from ischemia. }\end{array}$ \\
\hline 1990 & $\begin{array}{l}\text { Effect of the calcium antagonist, } \\
\text { nifedipine, on ischemic retinal } \\
\text { dysfunction. }\end{array}$ & $\begin{array}{l}\text { Crosson CE et } \\
\text { al }\end{array}$ & Pathological & $\begin{array}{l}\text { Hypothesizes that retinal degeneration associated with } \\
\text { ischemia may result from accumulation of calcium } \\
\text { intracellularly. The hypothesis is supported after rats treated } \\
\text { with calcium channel agonists were shown to have protection } \\
\text { against ischemic damage in the retina. }\end{array}$ \\
\hline 1991 & $\begin{array}{l}\text { Accumulation of amino acids } \\
\text { and hydroxyl free radicals in } \\
\text { brain and retina of gerbil after } \\
\text { transient ischemia. }\end{array}$ & $\begin{array}{l}\text { Delbarre } \mathrm{G} \text { et } \\
\text { al }\end{array}$ & Pathological & $\begin{array}{l}\text { Examines the levels of amino acids and hydroxyl free radicals } \\
\text { in gerbil cerebral ischemia through examination of the occular } \\
\text { fundus. The ischemic group in comparison to control shows } \\
\text { increased levels of aspartate, glutamate, GABA, and } 2,5 \\
\text { DHBA. }\end{array}$ \\
\hline 1992 & $\begin{array}{l}\text { Open-channel block of N- } \\
\text { methyl-D- aspartate (NMDA) } \\
\text { responses by memantine: } \\
\text { therapeutic advantage against } \\
\text { NMDA receptor-mediated } \\
\text { neurotoxicity. }\end{array}$ & Chen HS et al & Therapeutic & $\begin{array}{l}\text { Studies the effect of memantine, an adamantane derivative, on } \\
\text { channels activated by NMDA receptor stimulation. The article } \\
\text { shows that the drug blocks these channels, contributing to a } \\
\text { therapeutic effect against neurotoxicity in the animal model, } \\
\text { but unlike other similar drugs it is well tolerated clinically, } \\
\text { suggesting future clinical uses. }\end{array}$ \\
\hline 1995 & $\begin{array}{l}\text { Effect of Daflon } 500 \mathrm{mg}, \mathrm{a} \\
\text { flavonoid drug, on neurological } \\
\text { signs, levels of free radicals and } \\
\text { electroretinogram in the gerbil } \\
\text { after ischemia-reperfusion } \\
\text { injury. }\end{array}$ & $\begin{array}{l}\text { Delbarre B et } \\
\text { al }\end{array}$ & Therapeutic & $\begin{array}{l}\text { Studies the effects of Daflon } 500 \mathrm{mg} \text {, a flavanoid drug, on } \\
\text { ischemia-reperfusion injury. Concludes that the drug could } \\
\text { interact with hydroxyl free radicals, which have a deleterious } \\
\text { effect in ischemic tissues, particularly in the retina. }\end{array}$ \\
\hline 1995 & $\begin{array}{l}\text { Effect of piribedil, a D-2 } \\
\text { dopaminergic agonist, on } \\
\text { dopamine, amino acids, and free } \\
\underline{\text { radicals in gerbil brain after }} \\
\underline{\text { cerebral ischemia. }}\end{array}$ & $\begin{array}{l}\text { Delbarre B et } \\
\text { al }\end{array}$ & Therapeutic & $\begin{array}{l}\text { Tests the action of D-2 agonist piribedil on gerbil brains after } \\
\text { ischemia reprefusion/insult in order to observe if it inhibits } \\
\text { release of excitatory amino acids implicated in cerebral } \\
\text { ischemia. Finds that piribedil presents a neuroprotective effect } \\
\text { and reverses the increase of dopamine, exitatory amino acids, } \\
\text { and hydroxyl-free radicals after ischemia reperfusion/insult. }\end{array}$ \\
\hline 1996 & $\begin{array}{l}\text { Taurine in gerbil retina: changes } \\
\text { during ischemia reperfusion/ } \\
\text { insult (I.R.I.) and aging. }\end{array}$ & $\begin{array}{l}\text { Delbarre B et } \\
\text { al }\end{array}$ & Pathological & $\begin{array}{l}\text { Examines levels of taurine in gerbil retinas in animals effected } \\
\text { by ischemia and control animals at a variety of ages. The study } \\
\text { finds that animals from the ischemic group regularly increase } \\
\text { taurine levels in the retina throughout the course of their aging } \\
\text { while animals from the control group have low levels of taurine } \\
\text { at early ages, the levels reach a plateau, and then decrease with } \\
\text { age. }\end{array}$ \\
\hline 1997 & $\begin{array}{l}\text { Intravitreal injection of } \\
\text { ganglioside GM1 after ischemia } \\
\underline{\text { reduces retinal damage in rats. }}\end{array}$ & $\begin{array}{l}\text { Mohand-Said } \\
\text { S et al }\end{array}$ & Therapeutic & $\begin{array}{l}\text { Evaluates the protective effect of GM1 administered } \\
\text { intravitreally after ischemia on retinal lesions. Concludes that } \\
\text { GM1 given intravitreally successfully protects the rat retina } \\
\text { from pressure-induced ischemic injury and that this protection } \\
\text { could be of therapeutic interest. }\end{array}$ \\
\hline 1998 & $\begin{array}{l}\frac{\text { Tacrolimus (FK506) attenuates }}{\text { leukocyte accumulation after }} \\
\underline{\text { transient retinal ischemia. }}\end{array}$ & $\begin{array}{l}\text { Tsujikawa A } \\
\text { et al }\end{array}$ & Pathological & $\begin{array}{l}\text { Evaluates quantitatively the inhibitory effects of tacrolimus on } \\
\text { leukocyte rolling and on subsequent leukocyte accumulation in } \\
\text { vivo after transient retinal ischemia and the protective effects } \\
\text { of tacrolimus on ischemia- induced neural damage. }\end{array}$ \\
\hline
\end{tabular}




\begin{tabular}{|c|c|c|c|c|}
\hline Date & Article & Author & Category & Description \\
\hline & & & & $\begin{array}{l}\text { Successfully demonstrates this inhibitory effect and provides } \\
\text { quantitative analysis on the results. }\end{array}$ \\
\hline 1998 & $\begin{array}{l}\text { Acetylsalicylate administered } \\
\text { during simulated ischemia } \\
\text { reduces the recovery of neuronal } \\
\text { function in the in vitro rabbit } \\
\text { retina. }\end{array}$ & $\begin{array}{l}\text { Maynard KI et } \\
\text { al }\end{array}$ & Mechanistic & $\begin{array}{l}\text { Studies whether the effects of aspirin on ischemia are due to it } \\
\text { acting directly on the CNS or through some other method. } \\
\text { Concludes that lysine acetylsalicylate inhibits CNS } \\
\text { neurotransmission, but not phototransduction, in a } \\
\text { concentration- dependent manner. }\end{array}$ \\
\hline 2000 & $\begin{array}{l}\text { Chronic cerebral hypoperfusion: } \\
\text { loss of pupillary reflex, visual } \\
\text { impairment and retinal } \\
\text { neurodegeneration. }\end{array}$ & $\begin{array}{l}\text { Davidson CM } \\
\text { et al }\end{array}$ & Pathological & $\begin{array}{l}\text { Studies the effects of chronic cerebral ischemia on vision and } \\
\text { retina by performing permanent bilateral occlusions of } \\
\text { common cartoid arteries on adult rats. Procedure causes loss of } \\
\text { pupillary reflex and degeneration of photoreceptors and retinal } \\
\text { ganglion cells in a number of rats. }\end{array}$ \\
\hline 2002 & 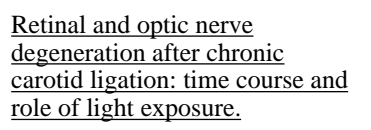 & $\begin{array}{l}\text { Stephens WD } \\
\text { et al }\end{array}$ & Pathological & $\begin{array}{l}\text { Examines the effects of chronic retinal ischemia in an animal } \\
\text { model involving permanent carotid occlusion. Finds that } \\
\text { ischemic damage to the optic nerve causes loss of pupillary } \\
\text { reflex and death of retinal ganglion cells in a subset of rats. }\end{array}$ \\
\hline 2003 & $\begin{array}{l}\text { Argatroban attenuates leukocyte- } \\
\text { and platelet-endothelial cell } \\
\text { interactions after transient retinal } \\
\text { ischemia. }\end{array}$ & $\begin{array}{l}\text { Miyahara S et } \\
\text { al }\end{array}$ & Pathological & $\begin{array}{l}\text { The study attempts to evaluate quantitatively the inhibitory } \\
\text { effects of the thrombin inhibitor argatroban on leukocyte- and } \\
\text { platelet-endothelial cell interactions after transient retinal } \\
\text { ischemia. It finds that argatroban treatment successfully } \\
\text { suppresses leukocyte- and platelet-endothelial cell interactions } \\
\text { after transient retinal ischemia. }\end{array}$ \\
\hline 2003 & $\begin{array}{l}\text { Functional and cellular } \\
\text { responses in a novel rodent } \\
\text { model of anterior ischemic optic } \\
\text { neuropathy. }\end{array}$ & $\begin{array}{l}\text { Bernstein SL } \\
\text { et al }\end{array}$ & Pathological & $\begin{array}{l}\text { Study creates a new rodent model for anterior ischemic optic } \\
\text { neuropathy (AION). Accomplishes a photoembolic stroke } \\
\text { model that is directly analogous to human AION through use } \\
\text { of histologic, electrophysiological, molecular-, and cell } \\
\text { biological methods. }\end{array}$ \\
\hline 2003 & $\begin{array}{l}\text { Non-erythroid functions of } \\
\text { erythropoietin. }\end{array}$ & $\begin{array}{l}\text { Gassmann M } \\
\text { et al }\end{array}$ & Pathological & $\begin{array}{l}\text { Discusses roles of EPO outside of Erythropoesis, showing the } \\
\text { expression of EPO and its receptor in the brain, spinal cord, } \\
\text { retina, and testis. Discusses the future of applications for EPO } \\
\text { in a clinical setting. }\end{array}$ \\
\hline 2004 & $\begin{array}{l}\text { Retinal ischemia: mechanisms of } \\
\text { damage and potential therapeutic } \\
\text { strategies. }\end{array}$ & $\begin{array}{l}\text { Osborne NN } \\
\text { et al }\end{array}$ & Therapeutic & $\begin{array}{l}\text { Discusses the myriad of emerging treatments that are } \\
\text { generating success in diminishing the negative effects of retinal } \\
\text { ischemia in animal models, and how translating these } \\
\text { treatments to clinical models is proving difficult. }\end{array}$ \\
\hline 2004 & $\begin{array}{l}\text { Effect of erythropoietin } \\
\text { axotomy- induced apoptosis in } \\
\text { rat retinal ganglion cells. }\end{array}$ & $\begin{array}{l}\text { Weishaupt JH } \\
\text { et al }\end{array}$ & Mechanistic & $\begin{array}{l}\text { Examines EPO signal transduction in vivo and the usefulness } \\
\text { of EPO in the prevention of the chronic, purely apoptotic } \\
\text { neuronal cell death that contributes to vision loss in glaucoma } \\
\text { and the progression of neurodegenerative diseases. Concludes } \\
\text { based on results that EPO has potential as a therapeudic } \\
\text { molecule against apoptotic neuronal cell death. }\end{array}$ \\
\hline 2004 & $\begin{array}{l}\text { Science review: recombinant } \\
\text { human erythropoietin in critical } \\
\text { illness: a role beyond anemia? }\end{array}$ & $\begin{array}{l}\text { Coleman } \mathrm{T} \text { et } \\
\text { al }\end{array}$ & Pathological & $\begin{array}{l}\text { Discusses the potential utility of EPO as a protective cytokine } \\
\text { in the context of acute critical illness and suggests parameters } \\
\text { for a proof-of-concept clinical study. }\end{array}$ \\
\hline 2005 & $\begin{array}{l}\text { Erythropoietin protects from } \\
\text { axotomy-induced degeneration } \\
\text { of retinal ganglion cells by } \\
\text { activating ERK-1/-2. }\end{array}$ & Kilic $\mathrm{U}$ et al & Therapeutic & $\begin{array}{l}\text { Examines the effect of Erythropoietin on the degeneration of } \\
\text { retinal ganglion cells in transgenic mouse line tg } 21 \text {. The results } \\
\text { reveal that the retinal ganglion cells of Epo transgenic tg } 21 \\
\text { mice were protected against degenaration in comparison to the } \\
\text { wild-type control group. }\end{array}$ \\
\hline
\end{tabular}

